\title{
Nursing concepts and theories
}

\author{
CONCEITOS E TEORIAS NA ENFERMAGEM \\ CONCEPTOS Y TEORÍAS EN ENFERMERÍA
}

\section{Regina Szylit Bousso ${ }^{1}$, Kátia Poles ${ }^{2}$, Diná de Almeida Lopes Monteiro da Cruz ${ }^{3}$}

\begin{abstract}
The theory framework of nursing science is built in a dynamic process that arises from practice and is reproduced through research, mainly by analysis and development of concepts and theories. This study presents a theory reflection on nursing knowledge construction and points out subsidies for future studies in the area. The interrelation among theory, research, and clinical practice is required for continuous development of nursing as a profession and science. Ideally, the practice must be based on theory that is validated by research. Therefore, theory, research, and practice affect each other reciprocally and continuously.
\end{abstract}

\section{DESCRIPTORS}

Nursing theory

Concept formation

Philosophy, nursing

Nursing research

\section{RESUMO}

O arcabouço teórico da ciência da enfermagem constrói-se em um processo dinâmico que tende a nascer da prática e que se reproduz na pesquisa, especialmente por meio da análise e do desenvolvimento de conceitos e teorias. O presente artigo tem como objetivo apresentar uma reflexão teórica sobre a construção do conhecimento em enfermagem e apontar subsídios para futuras pesquisas na área. A inter-relação entre a teoria, a pesquisa e a prática clínica é necessária para a continuidade do desenvolvimento da enfermagem como profissão e como ciência. Idealmente, a prática deve ser baseada nas teorias que são validadas pela pesquisa. Assim, teoria, pesquisa e prática afetam-se de maneira recíproca e contínua.

\section{DESCRITORES}

Teoria de enfermagem

Formação de conceito

Filosofia em enfermagem

Pesquisa em enfermagem

\section{RESUMEN}

El marco teórico de la ciencia de enfermería se construye en un proceso dinámico, que suele nacer de la práctica y que se reproduce en la investigación, especialmente a través del análisis y el desarrollo de conceptos y teorías. Este articulo tiene como objetivo presentar una reflexión teórica sobre la construcción del conocimiento de enfermería, y ofrecer subsidios para futuras investigaciones en el área. La interrelación entre la teoría, la investigación y la práctica clínica es necesaria para el continuo desarrollo de la enfermería como profesión y como ciencia. Lo ideal sería que la práctica se base en teorías que son validadas por la investigación. Por lo tanto, la teoría, la investigación y la práctica se afectan de manera recíproca y continua.

\section{DESCRIPTORES}

Teoría de enfermería Formación de concepto Filosofía en enfermería Investigación en enfermería

${ }_{1}^{1}$ PostDoctoral Professor, Department of Nursing Mother-Child and Psychiatric, Escola de Enfermagem, Universidade de São Paulo, São Paulo, SP, Brazil. szylit@usp.br ${ }^{2}$ Nurse. Adjunct Professor, Universidade Federal de São João Del-Rei, MG, Brazil. kpoles@usp.br 35ull professor, Department of MedicalSurgical Nursing, Universidade de São Paulo, São Paulo, SP, Brasil. dinamcruz@usp.br 


\section{INTRODUCTION}

The theory framework of nursing science is built in a dynamic process that arises from practice and is reproduced through research, mainly by analysis and development of concepts and theories. Science consists of movement from common sense to critical evaluation, which is often poorly defined or inadequately performed. The clarity of a particular concept could contribute to the construction of a body of knowledge in a given area, and lack of clarity results in less consistent science than is desired. The search for understanding and the concern about providing names for practice facts to facilitate reflection and action toward practice are driving forces behind concept development in nursing ${ }^{(1-2)}$.

The phenomena seen in nurses' experiences in practice should be investigated further so that their attributes can be identified. The most logical and effective way to enable a nurse to deeply examine a phenomenon is to begin defining the concept of interest. Such action will enable the development of theories directly related to clinical practice(3). The best way to do so is to first define the phenomenon or concept and then assess it thoroughly ${ }^{(4)}$.

The emphasis on analysis and development of a concept in nursing has increased in the past decade because researchers have sought to clarify problems that in the past were considered and accepted as common sense. This increase occurred because some concepts, which could be seen as obvious, include vague terminology, ambiguous definitions, and inconsistent theories ${ }^{(1,5)}$.

Therefore, analysis and concept development are closely related to the evolution and enhancement of nursing knowledge. As a result of continuous reformulation and refining of concepts, nurses gain a solid basis of knowledge. Hence, an important point in nursing, as in other disciplines, concerns concepts. For this reason, nursing researchers have proposed and used a number of strategies and methods for concept analysis and development.

Several methods for development and analysis of concepts are available ${ }^{(3)}$. Among these, the most used in nursing are concept analysis, as proposed by Walker and Avant ${ }^{(6)}$; evolutionary methods of concept analysis, developed by Rodgers $^{(7)}$; and a hybrid model ${ }^{(4)}$.

\section{WHAT IS A CONCEPT?}

There is no consensus on the definition of a concept. Concepts are described as abstraction, mental formulations, mental images, and words that represent mental images. Therefore, concepts are not self-evident or refer to the same type of thing ${ }^{(8-10)}$. Other authors point out that concepts have several meanings, uses, and definitions that are often described in words ${ }^{(11)}$.

A concept is considered an ideal or mental construction elaborated with regard to a phenomenon that is essential for research development and construction of the- ories $^{(12)}$. Concepts comprise abstract attributes of reality and, as a consequence, represent more than words and mental images because those do not capture the complex nature of these attributes ${ }^{(5)}$. Concepts can also be understood as cognitive and abstract representations of perceived reality built up by direct or indirect experiences ${ }^{(13)}$. Therefore, a concept must be included in a context in a manner that allows meaning and application, and thus advances knowledge in a specific area.

A concept is communicated using language with the intention that words, terms, and expressions represent the developed idea. Words, terms, or expressions are not the concept itself but rather represent it. The main requirement of words that designate the concept is that they are able to express throughout their meaning what really occurs in an empiric reality: i.e., the words used to designate a concept must reflect similar ideas to different persons ${ }^{(14)}$.

Concepts can be abstract (care, respect, collaboration) or relatively concrete (fever, pain, fatigue). They are created by words that enable people to communicate their meaning to the world and provide meaning to phenomena that could, directly or indirectly, be experienced ${ }^{(10)}$. A concept can be represented by a word (grief, empathy), two words (social isolation, chronic pain), or a phrase (health provider behaviors, multidisciplinary teamwork).

Concepts are like bricks of a wall, and they give science its structure. For this reason, scientific research explores or tests possible articulations among these bricks with the purpose of producing evidence to confirm, deny, or modify theories ${ }^{(15)}$.

\section{WHY SHOULD CONCEPTS BE STUDIED?}

Concepts are constructed by meanings of words. Studying concepts is considered essential for three main reasons:

1) Concepts are used to develop theories: The theories are constructed from concepts, and thus the elaboration of concept meaning is vital for construction of theories ${ }^{(8)}$.

2) Concepts can be operationalized: Concepts can be analyzed for their application in practice (e.g., respect ${ }^{(13)}$, collaboration $^{(16)}$, and die with dignity $\left.{ }^{(17)}\right)$.

3) Concepts can be used to enhance practice: By analyzing, concepts a professional can better understand the meaning of commonly used terms. For example, research that aims to explore the concept of dignity can help increase nurses' awareness of the importance of this concept and encourage them to appreciate the vulnerable position of patients who are receiving care ${ }^{(18)}$.

Concept analysis and development can be understood as a driving force to improve quality in practice. A problem in nursing is that several of the main terms used 
in the field, which are related to day-to-day practice, are imprecise and ambiguous. Therefore, words such as care, respect, and dignity, which reflect a special meaning for nurses, should be considered without ambiguity or confusion $^{(11)}$ in order to achieve similar status with other technical terms.

Another example is a study that analyzed and developed the concept of dying with dignity. For a child to die with dignity in a pediatric intensive care unit is a complex phenomenon whose definition remains vague or highly variable. The lack of clarity of this concept resulted in its use in a variety of inadequate situations. That study sought to improve understanding of the term in order to offer subsidies for child care, assist the child's family, and advance teaching and research on end-oflife care in pediatrics ${ }^{(17)}$.

However, how can this offering be done? How can thedie with dignity concept, or any other important concept for nurses, be clarified? How can the adequate and clear use of nursing terms be guaranteed?

Concept analysis presupposes that a concept was first introduced in the nursing literature and was then tested in field research. This process implies that a concept is decomposed and then rebuilt to contribute to nursing knowledge ${ }^{(9)}$. The objective of such analysis is to bring a concept as close as possible to use in research or clinical practice and, finally, to contribute to the development of test theories.

\section{CONCEPT ANALYSIS VERSUS CONCEPT DEVELOPMENT}

While concept analysis has often been considered a form of theoretical assessment based on the literature, concept development proposes a theoretical analysis and field work enabling a deep understanding of concepts $^{(19)}$. For this reason, concept analysis is conducted before the development of a particular concept because the research begins with critical analysis of literature and will continue with the study of how the concept is manifested in practice.

Once concept analysis is completed, the researcher must test the concept in descriptive studies, particularly qualitative studies, to better develop the concept as its use becomes explicit in real-life situations ${ }^{(3)}$.

\section{CONCEPT DETACHMENT}

\section{Critical analysis of the literature}

The first step in exploring a concept is critical analysis of the literature. This step is important because it shows the scientific rigor of the research, reduces prejudices of the researchers, clarifies the nature of conceptual problems, and helps the researchers to determine their study objective ${ }^{(4-5)}$.
All approaches to exploring concepts begin with critical analysis of the literature. This phase enables the researchers to identify the nature of the concept (i.e., the attributes that reflect the real definition of a concept) $)^{(5)}$.

A critical analysis of the literature is different from a literature review because in the latter the research has a specific topic. In critical assessment, the researchers critique or challenge the ideas of other authors. Such an approach helps the researchers to explore and develop the concept that will be investigated ${ }^{(13)}$. In addition, such assessment provides information in diverse conceptualizations of the concept and the contexts in which the concept was used by other researchers. Finally, the assessment gives information on implicit or explicit assumptions and evolution of concept coherence. This analysis produce insights, significant issues, and directions to be taken in the research ${ }^{(13)}$.

Exploring a concept means identifying attributes, antecedents, and consequences, as described below ${ }^{(4)}$.

\section{Attributes}

Concept analysis seeks to identify attributes that define the concept. Attributes are words or expressions used with frequency by authors to describe characteristics of a concept ${ }^{(7)}$.

The first step in exploring a concept consists of analyzing several uses of the concept by searching dictionaries and relevant nursing or non-nursing literature. The key question distills attributes from the critical analysis of the literature, thereby producing a conceptual order from chaos ${ }^{(6)}$.

\section{Antecedents}

Antecedents are understood as situations, events, or phenomena that precede the interesting concept. Antecedents help researchers understand the social context in which a concept is often used, as well as favoring the refinement of the concept ${ }^{(7)}$.

\section{Consequences}

The consequences of a concept concern events or situations resulting from its use ${ }^{(7)}$, as shown in Figure 1.

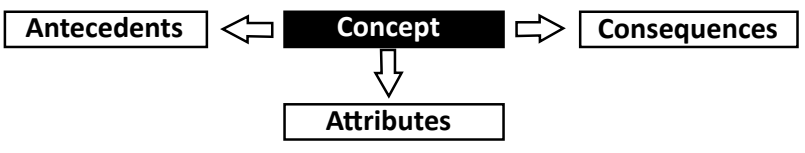

Figure 1 - Relationship among antecedents, attributes and consequences

\section{NURSING DIAGNOSIS AS CONCEPTS}

Nursing diagnosis is a way to express care needs that identify those who receive care, enabling application of 
possible nursing interventions. Such diagnoses also lead to possible standardized language among nurses and contribute to the development of nursing knowledge.

The NANDA International classification ${ }^{(20)}$ brings together a set of nursing diagnoses. Therefore, the language used in NANDA-I helps professionals to communicate their experiences with patients. It also contributes to patient care by classifying nursing phenomena and standardizing language among nurses.

Nursing diagnoses are scientific interpretations of data that appeared and that are used to guide planning, implementation, and evaluation of nursing practice. The use of nursing diagnoses gives more visibility to nurses, whose caregiving has previously been invisible or unrecognized ${ }^{(20)}$.

Defining characteristics and factors are related to nursing diagnoses. Those characteristics are passible clues of observations and checks. In this sense, defining characteristics could be understood as attributes of diagnosis or as concepts. Related factors concern the cause of a condition that prompted the diagnosis ${ }^{(20)}$. Therefore, related factors are understood as antecedents of nursing diagnosis.

Nursing diagnoses aim to guide nursing interventions and to achieve better results ${ }^{(20)}$. When each nursing diagnosis is considered as a concept, the effective results of nursing care would be the consequence of the concept.

An adequate nursing diagnosis enables nurses to articulate several manifestations of patients to a concept, and this concept can lead to a course of nursing action. In this way, diagnosis is a useful structure to guide nursing practice and to organize knowledge that serves as the basis for this practice ${ }^{(21)}$.

Although the potential for standardizing the language system is evident, the work on diagnosis categories and classification systems remains in its initial stages. This research highlights issues of the conceptual clarity of each diagnosis. Nursing diagnoses have a meaning only if they are seen as a concept that denotes a specific phenomenon ${ }^{(14)}$.

It is important to emphasize that in clinical settings, differentiating one diagnosis from another is extremely difficult. Hence, a patient's manifestation and the definitions for each diagnosis should be carefully considered ${ }^{(14)}$.

Studies that evaluate each diagnosis as a concept and that analyze relations between diagnoses that express related concepts could support diagnostic decisions in nursing and, as a consequence, advance professional practice ${ }^{(14)}$.

Standardizing diagnostic terms involves seeking an agreement within the nursing profession itself about the attribution of names or titles to situations focused on clinical nursing practice ${ }^{(14)}$.

\section{CONCEPTS AND THEORIES}

Words are loaded in theory, and the main reason for the proliferation of meanings is the proliferations of theories ${ }^{(22)}$. Theory determines the meaning of a concept. Therefore, a word that means something in the context of theory $A$ could mean something different in the context of theory $B$, and the difference could be more or less subtle.

Theories are considered structured words (i.e., it is the structure of words that gives sense to a theory). Therefore, the location of each word gives sense to those specific theories. If word structure is changed or different words are adopted for a specific concept, the meaning of the theory will change.

The single best way to clarify a concept is to explain the theory to which this concept is applied. However, adopting a specific theory does not end conflict. If the same term appears in different theories, it might generate a conflict. To solve such methodological problem, it is necessary to verify the appearance of the concept in different theories. A concept is not classified without a theoretical commitment through review of different theories in an attempt to define the concept that appears in different contexts ${ }^{(22)}$.

\section{FINAL CONSIDERATIONS}

Most authors consider concept analysis as the first step of a study on concepts. However, we believe that without a reflexive commitment of researchers, conceptual clarification is an arbitrary and empty exercise; i.e., the research first needs to establish the concept of interest and then analyze its applicability and relevance to advancing knowledge and clinical practice.

Given the potential of theoretical research to advance science, we highlighted the importance of choosing adequate models for analysis and development of concepts for which there are fewer studies in the literature.

Although it was thought that concepts could be always defined (i.e., they cannot be contested), this idea is now being questioned. Currently, it is understood that concepts are dynamic, variable, and dependent on the theoretical structure of which they are a part. This implies that concepts vary depending on their use and the context in which they are applied. Because knowledge is develops continuously, concepts must be constantly investigated and refined-they also evolve.

All theories represent a set of concepts that project a systemic view of a phenomenon. Theories describe, explain, diagnose, or prescribe measures for care practice, which offer scientific support for nursing actions.

Interrelation among theory, research, and clinical practice is needed for continuous development of nursing 
as a profession and a science. Ideally, practice must be based on theory that is validated by research. There- fore, theory, research, and practice affect each other reciprocally and continuously.

\section{REFERENCES}

1. Cowden TL, Cummings GG. Nursing theory and concept development: a theoretical model of clinical nurses' intentions to stay in their current positions. J Adv Nurs. 2012;68(7):1646-57.

2. Knafl KAQ, Deatrick JA. Knowledge synthesis and concept development in nursing. In: Rodgers BL, Knafl KA, editors. Concept development in nursing. 2nd ed. Philadelphia: Saunders; 2000. p. 39-54.

3. Wills EM, McEwen M. Bases teóricas para a enfermagem. Porto Alegre: Artmed; 2009.

4. Schwartz-Barcott D, Kim HS. An expansion and elaboration of the Hybrid Model of Concept Development. In: Rodgers BL, Knafl KA, editors. Concept development in nursing. 2nd ed. Philadelphia: Saunders; 2000. p.129-59.

5. Rodgers BL, Knafl KA. Introduction to concept development in nursing. In: Rodgers BL, Knafl KA, editors. Concept development in nursing. 2nd ed. Philadelphia: Saunders; 2000. p.1-6.

6. Walker LO, Avant CA. Strategies for theory construction in nursing. Upper Saddle River: Prentice Hall; 2004.

7. Rodgers BL. Concepts, analysis, and the development of nursing knowledge: the evolutionary cycle. J Adv Nurs. 1989;14(4):330-5.

8. Chinn PL, Kramer MK. Theory and nursing: a systematic approach. St Louis: Mosby; 1991.

9. Meleis A. Theoretical nursing: development and progress. Philadelphia: Lippincott Williams \& Wilkins; 2005.

10. Fawcett J. The relationship of theory and research. Philadelphia: F. Davis; 1999.

11. Rush KL, Ouellet LL. Mobility: a concept analysis. J Adv Nurs. 1993;18(3):486-92.
12. Simpson SM. Near death experience: a concept analysis as applied to nursing. J Adv Nurs. 2001;36(4):520-6.

13. Morse JM. Exploring the theoretical bases of nursing using advanced techniques of concept analysis. ANS Adv Nurs Sci. 1995;17(3):31-46.

14. Braga CG, Cruz DALM. Sentimento de impotência: diferenciação de outros diagnósticos e conceitos. Rev Esc Enferm USP. 2005;39(3):350-7.

15. Mota DDCF, Cruz DALM, Pimenta CAM. Fadiga: uma análise do conceito. Acta Paul Enferm. 2005;18(3):285-93.

16. Henneman EA, Lee JL, Cohen JI. Collaboration: a concept analysis. J Adv Nurs. 1995;21(1):103-9.

17. Poles K, Bousso RS. Dignified death: concept development involving nurses and doctors in pediatric intensive care units. Nurs Ethics. 2011;18(5):694-709.

18. Clark J. Defining the concept of dignity and developing a model to promote its use in practice. Nurs Times. 2010;106(20):16-9.

19. Öhlén J, Segesten K. The professional identity of the nurse: concept analysis and development. J Adv Nurs. 1998;28(4):720-7.

20. NANDA International. Diagnósticos de enfermagem da NANDA-I: definições e classificação 2009-2011. Porto Alegre: Artmed; 2010.

21. Creason NS, Camilleri DD, Kim MJ. Concept development in nursing diagnosis. In: Rodgers BL, Knafl KA, editors. Concept development in nursing: foundations, techniques, and applications. Philadelphia: Saunders; 1993. p. 217-34.

22. Paley J. How not to clarify concepts in nursing. J Adv Nurs. 1996;24(3):572-8. 